\title{
Utilized Theories by Nursing in the Care of People with an Ostomy: Integrative Review
}

\author{
Lays Pinheiro de Medeiros, Marjorie Dantas Medeiros Melo, \\ Bertha Cruz Enders, Suenia Silva de Mesquita Xavier, Julliana Fernandes de Sena, \\ Gabriela de Sousa Martins Melo, Jéssica Martinelli Martins de Assis, \\ Isabelle Katherinne Fernandes Costa Assunção \\ Department of Nursing, Health Science Center, Federal University of Rio Grande do Norte (UFRN), Central \\ Campus, Natal, Brazil \\ Email: isabellekfc@yahoo.com.br
}

Received 5 July 2016; accepted 27 August 2016; published 30 August 2016

Copyright (C) 2016 by authors and Scientific Research Publishing Inc.

This work is licensed under the Creative Commons Attribution International License (CC BY). http://creativecommons.org/licenses/by/4.0/

(c) (i) Open Access

\begin{abstract}
Objective: To identify in the literature the theories used by nursing professionals in the care of people with an ostomy. Method: It's about an integrative review of the literature used in the LILACS, BDENF, PubMed Central, CINAHL, Web of Science and SCOPUS database. Results: The sample was made of 18 publications. Most of them were studies published in the last five years (44.4\%), international publications $(72.2 \%)$, published in international periodicals $(66.7 \%)$, with level IV of evidence (83.3\%). It was identified in the articles that the nursing theories were shown as the most used by the nurses in the care of people with an ostomy (55.5\%), followed by the theories borrowed from psychology (38.9\%) and, finally, the theories borrowed from pedagogy (22.2\%). Conclusion: The nurses are using the assistance nursing models with a higher frequency to subsidize their surveys, as well as borrowed theories, mostly being performed and published internationally and with a low evidence level, highlighting the need of studies with a higher stringent methodology and, beyond this, analysis research of the used theories.
\end{abstract}

\section{Keywords}

Ostomy, Nursing Cares, Nursing Theory, Nursing Models

\section{Introduction}

The theories are made of a set of concepts and suppositions that show a global and systemic view of a determined phenomenon. They are used to explain, prescribe, describe and diagnose actions and can be applied in the 
practical, teaching, management and research field [1].

The importance to adopt the theoretical triad, research and clinical practice is clear as we perceive that the inter-relation between these concepts promotes the ongoing search in understanding the determinants of health problems to solve the needs of the individuals that are requiring an intervention to improve their health condition [1] [2].

However, the complexity in providing care to the population, demands from the nurse, a solidified knowledge and he must make good use of the used instruments in order to offer certainty in the assistance and to make a path to structure the nursing as a science. The nursing theories are an example of this kind of scientific tool.

In the nursing, the use of theories reflects the structure of self-sufficiency and the search to make a body of self-knowledge that meets the singularities of the profession and the social context [3]. To build this body of knowledge, the nursing professionals have identified representative phenomenon and acted upon them with specific views that innovate the know-how [4].

Some specific groups require a special attention from the professionals in reason of all the provoked nuances and the people with an ostomy are a part of those groups. Patients submitted to such procedure have their body image changed in a bad way by the stool evacuation in the ostomy pouch in the abdominal region [5].

The impact due to the making of an ostomy, brings various changes/difficulties to the individual that reflect in a modification of the life perspective, in the biological, psychological, social and spiritual aspects, contributing to reduction of his quality of life [6].

Faced by this situation, it's most important that the nurses use the nursing theories to support their experience and provide a quality assistance to these people. However, by learning about the used theories in nursing, it's important to remember that it evolves a lot during the last decades and that their knowledge foundation is a compilation of numerous different disciplines [7] and because of that, the nursing theories are not the only ones used in the practical assistance of the nurses.

In this overview, it's possible to see the need to extend and solidify the nursing knowledge by their body of self-knowledge, surpassing the technical barrier that is imposed to them in order to advance as a science. Because of that, it's necessary to evaluate the actual context of how and which theories are being used by nursing professionals in the care of people with an ostomy, through the execution of an integrative review of the literature for being a useful instrument and wide in the set of summary materials and data analysis, with a structured and clear methodology in order to establish a guidance and scientific base for the health workers to be applied in the health services [8].

Based on what has been exposed, the study had as purpose, to identify in the literature, the theories used by nursing professionals in the care of people with an ostomy.

\section{Method}

It's about an integrative review of the literature, which allows to make an actual source of knowledge about a determined problem and to summarize the available studies, to conduct the experience based on scientific knowledge [9].

To the development of this study, the following steps were used: theme identification and making of the research question, establishment of the conditions to include and exclude the studies, definition of the data that will be obtained from the selected studies, categorization of the studies, evaluation of the chosen studies, interpretation of the results and exhibition of the summary of information [10].

The step of data gathering occurred in December 2015, upon online search of the articles that answered the following guiding question: what are the theories that are being used by nursing in the care of patients with an ostomy?

The database used were from the Latin American Literature and Caribbean health sciences (LILACS), BNDEF—nursing accessed by the virtual library in health—BVS, PubMed Central, Cumulative Index to Nursing and Allied Health Literature (CINAHL), Web of Science and SciVerseScopus (SCOPUS).

During the investigation of the publications, non-controlled descriptors from the Medical Subject Heading $(\mathrm{MeSH})$ were used, in the English Language: "Ostomy"; "Nursing Care" "Theory". The linking of those descriptors upon the use of the Boolean operator AND.

To select the articles, the following conditions of inclusion were established: complete available articles in the database named above, no time and language restriction and that had submitted on their results at least one 
theory used in the care of people with an ostomy. The studies were counted only one time in the database, excluding the ones in editorial form, letter to the editor and literature review. The search for the articles in the databases flowchart and the acquiring of the selected articles is shown on Table 1.

To analyze the level of evidence, it was used as parameter the Joanna Briggs Institute—JBI that classifies the studies on the four levels of scientific evidence [11].

In relation to the analysis and data extraction, instruments with the purpose to incorporate the acquiring of the theories that shape the research were used. The instruments were adapted from the models available by the JBI and referred to the initial evaluation to determine if the studies met the inclusion conditions and if the theory was or not described, critical appreciation to evaluate the study and methodological aspects and description of the characteristics of the studies to make the data analysis easier [8].

Finally, after a detailed reading of the selected articles at the previous step, it was defined the 18 articles that integrated the final sample of this integrative review of the literature. About the ethical aspects of the studies, the authorship of the studied articles was respected.

\section{Results}

From the 18 articles selected on the sample, 8 (44.4\%) were published in the last five years, 13 (72.2\%) are international researches, 12 (66.7\%) published in international periodicals and 16 (88.9\%) presented level IV of evidence. Table 2 shows more information about this data.

The nursing theories were presented as the most used by the nurses in the care of people with an ostomy 10 (55.5\%), followed by the theories borrowed from psychology 7 (38.9\%) and, finally, the theories borrowed from pedagogy 4 (22.2\%). Table 3 and Table 4 present the details of the information regarding the use of these theories in the nursing care [12]-[24].

Most of the selected studies to the sample, 9 (50\%) used these theories applying them as theoretical references to analyze the data gathered. Others 6 (33.3\%) used the theory to guide dissertation texts about determined themes related to the ostomy. The rest, 3 (16.7\%) applied the theory directly to the person with an ostomy, performing the process and proposed steps by the theory and/or assistance model.

Those last ones [25]-[30] were not analyzed using the utilized instrument in this study, bearing in mind that they did not answered a lot of questions from the use of the instrument. However, they were not excluded in reason of being considered as a part of the available scientific literature about the study object in question, and, therefore, important in the characterization of the theories used in the researches performed by nurses about the care of the person with an ostomy.

\section{Discussion}

The nursing theories represent the formal expression of the empirical pattern of the knowledge of this science, and form the base of the progressive attribution of meaning to the Nursing on the basis of the preparation and

Table 1. Number of located studies (L), potentially relevant studies (R), excluded studies for being duplicated (D), selected for complete reading (S) and final sample (A) by linking the descriptors ostomy, nursing care and theory on the researched databases.

\begin{tabular}{|c|c|c|c|c|c|}
\hline \multicolumn{6}{|c|}{ Ostomy and nursing care and theory } \\
\hline Bases & $\mathrm{L}$ & $\mathrm{R}$ & $\mathrm{D}$ & $\mathrm{S}$ & A \\
\hline Lilacs & 7 & 7 & 0 & 7 & 4 \\
\hline Bdenf & 2 & 2 & 0 & 1 & 1 \\
\hline Cinahl & 44 & 17 & 3 & 12 & 10 \\
\hline Pubmed & 86 & 3 & 0 & 3 & 3 \\
\hline Scopus & 19 & 6 & 5 & 0 & 0 \\
\hline Web of science & 3 & 3 & 3 & 0 & 0 \\
\hline Total & 161 & 38 & 11 & 23 & 18 \\
\hline
\end{tabular}


Table 2. Characterization of the studies about the place of publication, year of publication, methodological aspects and level of scientific evidence.

\begin{tabular}{cccc}
\hline Place of publication & Year of publication & Methodological aspects & Level of evidence \\
\hline Brazil & 2014 & Transversal, descriptive and qualitative & IV \\
Brazil & 2013 & Transversal, descriptive and qualitative & IV \\
Brazil & 2008 & Case study & IV \\
Brazil & 2013 & Transversal, descriptive, quantitative and qualitative & IV \\
USA & 2005 & Case study & IV \\
USA & 1997 & Case study & IV \\
USA & 2008 & Transversal, analytical e quantitativeandqualitative & III.2 \\
USA & 2002 & Transversal, analytical and quantitative & IV \\
USA & 1999 & Transversal, analytical and quantitative & IV \\
USA & 2011 & Transversal, descriptive and qualitative & IV \\
USA & Longitudinal, descriptive and quantitative & III.3 \\
USA & 2015 & Transversal, descriptive and qualitative & IV \\
Brazil & 2014 & Bibliographic research & IV \\
USA & 2007 & Bibliographic research & IV \\
USA & 2012 & Bibliographic research & IV \\
USA & 2015 & Bibliographic research & IV \\
USA & 1999 & Bibliographic research & IV \\
USA & 1996 & Bibliographic research & IV
\end{tabular}

Table 3. Distribution of the studies from the step of critical appreciation of the theories.

\begin{tabular}{|c|c|c|c|c|c|}
\hline ID & $\begin{array}{l}\text { The } \\
\text { theorywasdescribed? }\end{array}$ & $\begin{array}{l}\text { The theoretical model used is } \\
\text { based in one single or mul- } \\
\text { tiple theory? }\end{array}$ & $\begin{array}{l}\text { The chosen methodology is } \\
\text { consistent with what the } \\
\text { theory implies? }\end{array}$ & $\begin{array}{l}\text { The theory is } \\
\text { being applied, } \\
\text { tested, created or } \\
\text { discussed? }\end{array}$ & $\begin{array}{l}\text { The limits and } \\
\text { potentials of the } \\
\text { theories were } \\
\text { evaluated? }\end{array}$ \\
\hline 12 & Yes & Single theory & Yes & Yes & No \\
\hline 13 & Yes & Single theory & Yes & Yes & No \\
\hline 14 & Yes & Single theory & No & Yes & No \\
\hline 15 & Yes & Single theory & Yes & Yes & No \\
\hline 16 & Yes & Single theory & Yes & Yes & No \\
\hline 17 & Yes & Single theory & Yes & Yes & No \\
\hline 18 & Yes & Single theory & No & Yes & No \\
\hline 19 & Yes & Single theory & Yes & Yes & No \\
\hline 20 & Yes & Multiple & Yes & Yes & No \\
\hline 21 & Yes & Single theory & Yes & Yes & No \\
\hline 22 & Yes & Single theory & No & Yes & No \\
\hline 23 & Yes & Single theory & No & Yes & No \\
\hline
\end{tabular}

communication of a specific body of knowledge that subsidize the professional experience. This way, the theories are presented to the Nursing as a fundamental instrument to make it possible the external recognition of the profession and self-sufficiency, making the theoretical bases that support the research, teaching and experience clear [4].

The evaluation process of the nursing theories is an essential component in the development of the nursing knowledge and show a critical element in the construction of the discipline. The evaluation of a theory can help 
Table 4. Distribution of the studies from the step of the extraction of the data from the theories.

\begin{tabular}{|c|c|c|c|c|}
\hline ID & Used theory & Author(s) & Study objective & $\begin{array}{l}\text { Theory (applied, } \\
\text { tested, created or } \\
\text { discussed?) }\end{array}$ \\
\hline 12 & Transitions theory & Afaf Meleis & $\begin{array}{l}\text { Know the facilitators of the transition process of the } \\
\text { dependency to the self-care of a person with an ostomy. }\end{array}$ & Applied \\
\hline 13 & Self-care theory & $\begin{array}{l}\text { Dorothea E. } \\
\text { Orem }\end{array}$ & $\begin{array}{l}\text { Identify the constraint factors to the self-care in patients with an } \\
\text { ostomy and verify knowledge and experience about the care with } \\
\text { an ostomy. }\end{array}$ & Applied \\
\hline 14 & Self-care theory & $\begin{array}{l}\text { Dorothea E. } \\
\text { Orem }\end{array}$ & $\begin{array}{l}\text { Apply the Self-care Theory of Orem in the assistance of the patient } \\
\text { with an ostomy. }\end{array}$ & Applied \\
\hline 15 & $\begin{array}{l}\text { Basic human needs } \\
\text { theory }\end{array}$ & Wanda Horta & $\begin{array}{l}\text { Describe the daily problems lived by patients with Urinary } \\
\text { Diversion and relate them with the Basic Human Needs Theory of } \\
\text { Wanda Horta. }\end{array}$ & Applied \\
\hline 16 & Self-care theory & $\begin{array}{l}\text { Dorothea E. } \\
\text { Orem }\end{array}$ & $\begin{array}{l}\text { Describe the interventions made to promote the self-care of and } \\
\text { elder with intestinal ostomy. }\end{array}$ & Applied \\
\hline 17 & $\begin{array}{l}\text { Cultural diversity and } \\
\text { universal theory }\end{array}$ & $\begin{array}{l}\text { Madeleine } \\
\text { Leininger }\end{array}$ & $\begin{array}{l}\text { Describe a theory of nursing that support the meaning of } \\
\text { cultureasan essential concept of the nursing experience. }\end{array}$ & Applied \\
\hline 18 & $\begin{array}{l}\text { Transpersonal care } \\
\text { theory }\end{array}$ & Jean Watson & $\begin{array}{l}\text { Analyze the spiritual quality of life of the seniors with intestinal } \\
\text { ostomy. }\end{array}$ & Applied \\
\hline 19 & Family system theory & $\begin{array}{l}\text { Von } \\
\text { Bertallanfy }\end{array}$ & $\begin{array}{l}\text { Investigate the relation between the familiar dynamics and control } \\
\text { locus of health in families that had a member with an ostomy. }\end{array}$ & Applied \\
\hline 20 & $\begin{array}{l}\text { Adaptation model and } \\
\text { stress theory }\end{array}$ & $\begin{array}{l}\text { Callista Roy e } \\
\text { Lazarus \& } \\
\text { Folkman }\end{array}$ & $\begin{array}{l}\text { Identify which factors contribute to the post-surgery } \\
\text { adjustment of patients that had been submitted to a surgery of } \\
\text { permanent colostomy. }\end{array}$ & Applied \\
\hline 21 & Ecological social theory & $\begin{array}{l}\text { M. Powell } \\
\text { Lawton }\end{array}$ & $\begin{array}{l}\text { Identify the factors that hinder or ease the detection and } \\
\text { treatment of an ostomy and skin issues. }\end{array}$ & Applied \\
\hline 22 & Self-care theory of orem & $\begin{array}{l}\text { Dorothea E. } \\
\text { Orem }\end{array}$ & $\begin{array}{l}\text { Investigate the assistance of perioperative nursing and } \\
\text { methods to improve the quality of life. }\end{array}$ & Applied \\
\hline 23 & Stress theory & $\begin{array}{l}\text { Lazarus \& } \\
\text { Folkman }\end{array}$ & $\begin{array}{l}\text { Describe the strategies developed by the patients with } \\
\text { digestive ostomy to deal with their situation. }\end{array}$ & Applied \\
\hline
\end{tabular}

determine which model and/or theory is more appropriated to determined practical and research situations, as well as help in the comparison and explication of a same nursing phenomenon [30].

Despite the importance of this process, the study's results show the gap in this aspect of the production analysis, bearing in mind that none of the articles that compose the sample have the goal of analyzing any theory. Even so, some studies used theoretical references, of both Nursing and borrowed, to support the care of people with an ostomy, a step that could be justified and credited after the analysis of those theories in this specific population.

The 18 articles of the sample from this study show that the quantitative of the production referring the use of the nursing theories, or borrowed, used by nurses in the care of people with an ostomy, is still small, when compared to the numbers of publications about the theme, of both national and international scope [31].

This way, the knowledge and use of nursing theories must be each time more included to the nursing actions, because they surround and give visibility to the know-how of the profession, differentiating them from the others health classes. The college education that reflects directly in the knowledge of the nurses about the theories has the mission to foster and stimulate the improvement of the use of the theories in the most diverse areas of nursing [32].

Despite this, the nursing experience is, a lot of times, based by a mental model that each nurse, or group of nurses, adopt to substantiate their actions from the clinical practice and personal experiences, resulting in a shared knowledge that use, or do not use, the theoretical foundations that can be clearly defined, recognizing the importance of this definition during the professional formation [33].

Beyond this, some studies show the deficit on the knowledge of the professionals about the theoretical device of the nurses, highlighting the difficulties in the choice of a theoretical positioning that permeate the experience and supply of a nursing teaching with quality that support and bring closer the theoretical scientific know-how of the assistance and professional practical action. Such results reflect negatively in the self-sufficiency production of the assistance and scientific care of nursing [34] [35]. 
It is possible to see that most 11 (61.1\%) of the results of this revision is composed by studies that used theoretical reference borrowed to subsidize the research about the nursing care to people with an ostomy, being the theories of psychology and pedagogy the ones most quoted.

The use of borrowed theories was occurring as the nursing care identified the multiplicity of determinant aspects and constraints of the health-disease process. Thereby, to supply integral care, or build a wide theoretical model, it's required of the nurses to consider factors like physical, behavior, social, economics, psychological, among others, that are involved in the health assistance of people with intestinal ostomy [7].

The study of those elements that permeate the care, and their incorporation of them to the planning, execution and evaluation of the nursing care, form the use of borrowed theories. This way, the psychology shows concepts and theories that are clearly needed as a technical support in the health assistance of this population. The body image is one of them, being one of the main aspects that interfere in the quality of life and adaptation of the person with an ostomy [7] [18] [36] [37].

The stress, approached by the psychologists Lazarus and Strauss, also show a well explored field by nurses that study the adaptive process of the person with an intestinal ostomy. The adaptive and self-care needs, body image disorder, depression, social isolation, changes in the sexual functions and reduction of the independency are some of the factors frequently found in the literature that substantiate the care of those people [37]-[40].

Other theory from psychology that subsidize the care of people with an ostomy is the System Family Theory, present in all the sample studies. The family must be totally inserted in all the stages of the care of the person with an ostomy, bearing in mind that in the first months the adaptive demand and the care with the pouch generally require family support [41].

The person's family also receive a high emotional load that is present since the health-disease process that gave origin to the ostomy, stage of rehabilitation, treatment and stays during all the adaptive curse of the person with an ostomy. Some family reports reflect the high physical and psychological demands that permeate the care, or even the aid, to the person with an ostomy, that requires an acquisition of new abilities, time availability, emotional and financial support [42].

The theories from pedagogy represent 4 (22.2\%) of the total of the studies that are part of the sample. This amount shows the importance of the knowledge related to the educative process to the person with an ostomy, as well as revealing this function of the nurse in the care to those people. The education in health is shown as one of the most remarkable interventions of nursing in the promotion of self-care, reflecting directly in the quality of life and adaptation of the individuals with an ostomy [43] [44].

There are various strategies of teaching to people with an ostomy, which use a theoretical device from pedagogy and nursing, coating itself with innovative technologies, to provide the professional of nursing the maximum of pedagogical options to attend the educational needs of the greatest number of people with an ostomy and their relatives [43].

The nursing theories represent the majority of the studies that form the sample $10(55.5 \%)$ being $8(80 \%)$ assistance models. The assistance models present themselves as the first theoretical concepts and denote a more abstract and wide level of knowledge of nursing, show from the global point of view, are not specific, present abstract and non-operational defined concepts and generally are not possible to test. The use of assistance models can direct the professional experience of the nurse providing him with the guidelines to the planning, execution and evaluation of the nursing care, being possible to analyze them in the perspective of various situations and populations [7] [45].

On the other hand, 5 (50\%) of the studies that were about the nursing theories used the Theory of Orem. The General Theory of Orem is formed by three theoretical constructors: The Self-care, the deficiencies of the selfcare and the nursing systems, making the emphasis on the theoretical model in the promotion of self-care aiming the improvement of the quality of life, health and well-fare of the patients clearer. The majority of the studies made using this model has elected as target audience individuals with chronic needs, explored the theory in its entirety and had as a goal to improve the process of care [46].

After the preparation, the person with an ostomy needs to acquire knowledge and abilities in order to take care, observe and protect the ostomy in the best way possible. The orientations referent to this must be realized as soon as possible, still during the internment, however, as this is not granted, the associations of people with an ostomy present themselves as a system of support and education to promote the know-how and the experience needed to the care of the ostomy. This way, the Theory of Orem provides subsidies to direct the nursing experience in the care of the person with an ostomy aiming the self-care and consequently improves adaptation in the quality of life [13]. 
Another model of nursing present in the sample of this study is the Basic Human Needs Theory of Wanda Horta. It's about a Brazilian theory that nowadays has been the foundation of the preparation and implementation of the nursing process in six stages in various institutions, being, therefore, another option of theoretical contribution to subsidize the assistance provision of nursing directed and systematized [47] [48].

However, it's possible to see that, although recognizing the importance of the Systematization of the nursing assistance, the knowledge referent to this process still needs to be learned by the professionals, since a lot of them don't know even the theory that it supports [47].

To close, only two studies [12] [21] used the theories of medium range, transitions theory and transpersonal care theory, which are lesser wide than the big theories, they present a medium view of reality, therefore, are more specific then the assistance model, or big theory, have a limited amount of concepts relatively precise and operationally defined, distinctly declared propositions, can generate hypothesis that are possible to test and can evolve from the assistance models [7].

This possibility of testing in practice gives advantages to the results referent to the theories of medium range identified in this studies, being them the Cultural Diversity and Universal Theory of Leiniger and the Transitions Theory of Meleis. The purpose of the first is to generate knowledge related to the nursing care of people that value their cultural heritage and their way of life, having as a goal to provide the care culturally coherent to individuals of various cultures. On the other hand, the last one, is about the process of transition in a patient after the changes in his life and disease patterns.

Both theories are clearly visualized as possibilities of choice to be applied during the practice of the nursing assistance to people with an ostomy, bearing in mind that the adaptive process and the impact of the ostomy in the lives of the people can change in relation to the understanding of the health-disease process in determined cultures, as well as demands in the care during the transition process after this condition are various and are subject to changes considering the determinants and constraints of health [7].

This being said, the use of assistance models, the nursing and borrowed theories are presented in the literature as possibilities of the theoretical device capable of subsidizing the professionals experience in the care of the person with an ostomy and their relatives. Furthermore, it's clear that the theories borrowed presents a fundamental part in the construction of nursing knowledge, bearing in mind that the subsidy provided that ends in a vision of the nursing of a determined phenomenon.

\section{Conclusions}

After the realization of this study, it is possible to conclude that the nurses have been using the nursing theories with a higher frequency in comparison to the borrowed theories, followed by the borrowed theories from psychologic and pedagogy.

It's possible to see the increase in the scientific productions that clearly shows the use of one theory in the last five years, being most of the studies made and published in international territory and with level IV of evidence, in other words, it is needed that the studies with higher level of evidence should be used in order to provide reliable and safe subsidy to the science of nursing to lay the foundation of the professional experience and the researches in this field.

It's also possible to understand a gap in the literature referring to the analysis of the used theories in the care of people with an ostomy, especially about the assistance models of nursing. It's also necessary to point the need of studies with a higher level of evidence, which could be foundations to the practice of nursing in a safer and more efficient way.

This study provides to the nurses that aid people with an ostomy, and their relatives, various options of theories and assistance models that have already been used to support researches related to this theme, which can be tested and applied in individuals with an ostomy in other territories, as well as the analysis of them, which strengthen and enrich the specific knowledge of nursing, fortifying it as a health science.

To close, this study demonstrates the scientific production aiming the direction to its praxis, considering the important need to bring the theory, which is clearly defined, closer to the practice, ending in the immersion of the being in the signification of his attitudes as a nurse.

\section{References}

[1] Bousso, R.S., Poles, K. and Cruz, D.A.L.M. (2014) Nursing Concepts and Theories. Revista da Escola de Enfermagem 
da USP, 48, 141-145. http://www.scielo.br/scielo.php?script=sci_arttext\&pid=S0080-62342014000100141 http://dx.doi.org/10.1590/s0080-623420140000100018

[2] Freudenberg, N.Eng.E., Flay, B., Parcel, G., Rogers, T. and Wallerstein, N. (1995) Strengthening Individual and Community Capacity to Prevent Disease and Promote Health: Searching of Relevant Theories and Principles. Health Education Quarterly, 22, 290-306. http://www.ncbi.nlm.nih.gov/pubmed/7591786 http://dx.doi.org/10.1177/109019819402200304

[3] Schaurich, D. and Crossetti, M.G.O. (2010) Produção de Conhecimento sobre Teorias de Enfermagem. Escola Anna Nery Revista de Enfermagem, 14, 182-188. http://www.scielo.br/pdf/ean/v14n1/v14n1a27.pdf

[4] Garcia, T.R. and Nóbrega, M.M.L. (2004) Contribuição das teorias de enfermagem para a construção do conhecimento da área. Revista Brasileira de Enfermagem, 57, 228-232. http://www.scielo.br/pdf/reben/v57n2/a19v57n2.pdf http://dx.doi.org/10.1590/S0034-71672004000200019

[5] Nascimento, C.M.S., Trindade, G.L.B., Luz, M.H.B.A. and Santiago R.F. (2011) Vivência do paciente estomizado: Uma contribuição para a assistência de enfermagem. Texto \& Contexto Enfermagem, 20, 557-564. http://www.scielo.br/pdf/tce/v20n3/18.pdf

[6] Santana, J.C.B., Dutra, B.S., Tameirão, B.A., Silva, P.F., Moura, I.C. and Campos, A.C.V. (2010) O significado de ser colostomizado e participar de um programa de atendimento ao ostomizado. Cogitare Enfermagem, 15, 631-638. http://ojs.c3sl.ufpr.br/ojs2/index.php/cogitare/article/view/20358 http://dx.doi.org/10.5380/ce.v15i4.20358

[7] McEwen, M. and Wills, E.M. (2009) Bases teóricas da enfermagem. 2nd Edition, Artmed, Porto Alegre.

[8] Cassia, B.S. and Tatiana, Y. (2011) Revisão sistemática de teorias: uma ferramenta para avaliação e análise de trabalhos selecionados. Revista da Escola de Enfermagem da USP, 45,1507-1514. http://dx.doi.org/10.1590/S0080-62342011000600033

[9] Botelho, L.L.R., Cunha, C.C.A. and Macedo, M. (2011) O método da revisão integrativa os estudos organizacionais. Gestão e Sociedade, 5, 121-136. http://www.gestaoesociedade.org/gestaoesociedade/article/view/1220/906

[10] Mendes, K.D.S., Silveira, R.C.C.P. and Galvão, C.M. (208) Revisão integrativa: Método de pesquisa para a incorporação de evidências na saúde e na enfermagem. Texto \& Contexto Enfermagem, 17, 758-764. http://www.scielo.br/scielo.php?pid=S0104-07072008000400018\&script=sci_arttext

[11] Karino, M.E. and Felli, V.E.A. (2012) Enfermagem baseada em evidências: Avanços e inovações em revisões sistemáticas. Ciência, Cuidado e Saúde, 11, 11-15. http://periodicos.uem.br/ojs/index.php/CiencCuidSaude/article/view/17048/pdf

[12] Mota, M.S., Gomes, G.C., Petuco, V.M., Heck, R.M., Barros. E.J.L. and Gomes V.L.O. (2015) Facilitadores do processo de transição para o autocuidado da pessoa com estoma: Subsídios para Enfermagem. Revista da Escola de Enfermagem da USP, 49, 82-88. http://www.scielo.br/pdf/reeusp/v49n1/pt 0080-6234-reeusp-49-01-0082.pdf http://dx.doi.org/10.1590/S0080-623420150000100011

[13] Menezes, L.C.G., Guedes, M.V.C., Oliveira, R.M., Oliveira, S.K.P., Meneses, L.S.T. and Castro, M.E. (2013) Prática de autocuidado de estomizados: Contribuições da teoria de Orem. Revista da Rede de Enfermagem do Nordeste, 14, 301-310. http://www.revistarene.ufc.br/revista/index.php/revista/article/view/235/pdf

[14] Sampaio, F.A.A., Aquino, P.S., Araújo, T.L. and Galvão, M.T.G. (2008) Assistência de enfermagem a paciente com colostomia: Aplicação da teoria de Orem. Acta Paulista de Enfermagem, 21, 94-100. http://www.scielo.br/scielo.php?pid=S0103-21002008000100015\&script=sci_arttext\&tlng=pt http://dx.doi.org/10.1590/S0103-21002008000100015

[15] Ramos, R.C.A., Costa, C.M.A., Martins, E.R.C., Clos, A.C., Francisco, M.T.R. and Spíndola, T. (2013) Pacientes com derivações urinárias: Uma abordagem sobre as necessidades humanas básicas afetadas. Revista Enfermagem UERJ, 21, 337-342. http://www.e-publicacoes.uerj.br/index.php/enfermagemuerj/article/view/7516/5439

[16] Mendonça, R.S., Valadão, M., Castro, L. and Camargo, T.C. (2007) A Importância da consulta de Enfermagem em pré-operatório de ostomias intestinais. Revista Brasileira de Cancerologia, 53, 431-435. http://www.inca.gov.br/rbc/n_53/v04/pdf/artigo5.pdf

[17] Williams, J. (2012) Patient Stoma Care: Educational Theory in Practice. British Journal of Nursing, 21, 786-794. http://www.ncbi.nlm.nih.gov/pubmed/22874778

[18] Taylor, C. (2015) Body Image Concerns after Colorectal Cancer Surgery. British Journal of Nursing, 24, S8-S14. http://www.ncbi.nlm.nih.gov/pubmed/26018183

[19] Metcalf, C. (1999) Stoma Care: Empowering Patients through Teaching Practical Skills. British Journal of Nursing, 8, 593-600. http://www.ncbi.nlm.nih.gov/pubmed/10711005

[20] Martínez, L.A. (2005) Self-Care for Stoma Surgery: Mastering Independent Stoma Self-Care Skills in an Elderly Woman. Nursing Science Quarterly, 18, 66-69. http://www.ncbi.nlm.nih.gov/pubmed/15574699 
[21] Zoucha, R. and Zamarripa, C. (1997) The Significance of Culture in the Care of the Client with an Ostomy. Journal of Wound Ostomy \& Continence Nursing, 24, 270-276. http://www.ncbi.nlm.nih.gov/pubmed/9376903 http://dx.doi.org/10.1016/s1071-5754(97)90102-9

[22] Baldwin, C.M., Grant, M., Wendel, C., Rawl, S., Schmidt, C.M., Ko, C. and Krouse, R.S. (2008) Influence of Intestinal Stoma on Spiritual Quality of Life of U.S. Veterans. Journal of Holistic Nursing, 26, 185-194. http://www.ncbi.nlm.nih.gov/pubmed/18664602 http://dx.doi.org/10.1177/0898010108315185

[23] Wong, V.K. and White, M.A. (2002) Family Dynamics and Health Locus of Control in Adults with Ostomies. Journal of Wound Ostomy \& Continence Nursing, 29, 37-44. http://www.ncbi.nlm.nih.gov/pubmed/11810073

[24] Golis, A.M. (1996) Sexual Issues for the Person with an Ostomy. Journal of Wound Ostomy \& Continence Nursing, 23, 33-37. http://www.ncbi.nlm.nih.gov/pubmed/8704848 http://dx.doi.org/10.1016/s1071-5754(96)90114-x

[25] Piwonka, M.A. and Merino, J.M. (1999) A Multidimensional Modeling of Predictors Influencing the Adjustment to a Colostomy. Journal of Wound Ostomy \& Continence Nursing, 26, 298-305. http://www.ncbi.nlm.nih.gov/pubmed/10865614

[26] Bell, S.E. (2003) Community Health Nursing, Wound Care, and...Ethics? Journal of Wound Ostomy \& Continence Nursing, 30, 259-265. http://www.ncbi.nlm.nih.gov/pubmed/14560284 http://dx.doi.org/10.1016/s1071-5754(03)00352-8

[27] McMullen, C.K., Wasserman, J., Altschuler, A., Grant, M.L., Hornbrook, M.C., Liljestrand. P., Briggs, C. and Krouse, R.S. (2011) Untreated Peristomal Skin Complications among Long-Term Colorectal Cancer Survivors with Ostomies: Lessons from a Study of Family Caregiving. Clinical Journal of Oncology Nursing, 15, 644-650.

http://www.ncbi.nlm.nih.gov/pubmed/22119975 http://dx.doi.org/10.1188/11.cjon.644-650

[28] Ma, L., Liu, L., Shen, H., Dan, D., Wang, L. and Deng, Y.H. (2015) The Perioperative and Convalescence Nursing of 5 Cases of Monti Ileovesicostomy. International Journal of Clinical and Experimental Medicine, 8, 2887-2892. http://www.ncbi.nlm.nih.gov/pubmed/25932250

[29] Bonill-de-las-Nieves, C., Celdrán-Mañas, M., Hueso-Montoro, C., Morales-Asencio, J.M., Rivas-Marín, C. and Fernández-Gallego, M.C. (2014) Living with Digestive Stomas: Strategies to Cope with the New Bodily Reality. Revista Latino-Americana de Enfermagem, 22, 394-400. http://www.ncbi.nlm.nih.gov/pubmed/25029049 http://dx.doi.org/10.1590/0104-1169.3208.2429

[30] Eun-Ok, Im. (2015) The Current Status of Theory Evaluation in Nursing. Journal of Advanced Nursing, 71, $2268-2278$. http://onlinelibrary.wiley.com/doi/10.1111/jan.12698/pdf http://dx.doi.org/10.1111/jan.12698

[31] Freitas, L.S., Queiroz, C.G., Medeiros, L.P., Melo, M.D.M., Andrade, R.S. and Costa, I.K.F. (2015) Indicadores do resultado de enfermagem autocuidado da ostomia: Revisão integrativa. Cogitare Enfermagem, 20, 618-625. http://ojs.c3sl.ufpr.br/ojs/index.php/cogitare/article/view/40045

[32] Backes, D.S., Grando, M.K., Gracioli, M.S.A., Pereira, A.D., Colomé, J.S. and Gehlen, M.H. (2012) Vivência teóricoprática inovadora no ensino de enfermagem. Escola Anna Nery, 16, 597-602. http://www.scielo.br/pdf/ean/v16n3/24.pdf

[33] Amaducci, G., Lemmi, M., Prandi, M., Saffioti, A., Carpanoni, M. and Mecugni, D. (2013) La pratica infermieristicabasata sui modelliteorici: Uno studio qualitativo sullapercezionedegliInfermieri. Professioni Infermieristiche, 66, 99108. http://www.profinf.net/pro3/index.php/IN/article/view/25

[34] Ruiz, S.S., Parra, M.L., Pelaez, S.V. and Sabater, D.A. (2008) Perspectiva de laenfermería de un centro sociosanitario sobre laaplicabilidad y utilidad de los modelos enfermerosenlapráctica. Gerokomos, 19, 184-189. http://scielo.isciii.es/pdf/geroko/v19n4/184rincon.pdf

[35] Matos, J.C., Luz, G.S., Marcolino, J.S., Carvalho, M.D.B. and Pelloso, S.M. (2011) Ensino de teorias de enfermagem em Cursos de Graduação em Enfermagem do Estado do Paraná—Brasil. Acta Paulista de Enfermagem, 24, 23-28. http://www.scielo.br/pdf/ape/v24n1/v24n1a03.pdf

[36] Salomé, G.M. and Almeida, S.A. (2014) Association of Sociodemographic and Clinical Factors with the Self-Image and Self-Esteem of Individuals with Intestinal Stoma. Journal of Coloproctology, 34, 159-166. http://www.scielo.br/scielo.php?script=sci_arttext\&pid=S2237-93632014000300159 http://dx.doi.org/10.1016/j.jcol.2014.05.005

[37] Batista, M.R.F.F., Rocha, F.C.V., Silva, D.M.G. and Júnior, F.J.G.S. (2011) Autoimagem de clientes com colostomia em relação à bolsa coletora. Revista Brasileira de Enfermagem, 64, 1043-1047. http://www.scielo.br/scielo.php?script=sci_arttext\&pid=S0034-71672011000600009 http://dx.doi.org/10.1590/s0034-71672011000600009 
[38] Sun, V., Grant, M., McMullen, C.K., Altschuler, A., Mohler, M.J., Hornbrook, M.C., Herrinton, L.J., Baldwin, C.M. and Krouse, R.S. (2013) Surviving Colorectal Cancer: Long-Term, Persistent Ostomy Specific Concerns and Adaptations. Journal of Wound Ostomy \& Continence Nursing, 40, 61-72. http://www.ncbi.nlm.nih.gov/pubmed/23222968 http://dx.doi.org/10.1097/won.0b013e3182750143

[39] Mols, F., Lemmens, V., Bosscha, K., Broek, W.V.D. and Thong, M.S.Y. (2014) Living with the Physical and Mental Consequences of an Ostomy: A Study among 1 - 10-Year Rectal Cancer Survivors from the Population-Based Profiles Registry. Psycho-Oncology, 23, 998-1004. http://dx.doi.org/10.1002/pon.3517

[40] Melo, M.D.M., Medeiros, L.P., Queiroz, C.G., Melo, G.S.M., Liberato, S.M.D. and Costa, I.K.F. (2015) Revisão integrativa das características definidoras do diagnóstico de enfermagem: Disposição para resiliência melhorada em ostomizados. Revista Mineira de Enfermagem, 19, 779-785. http://www.reme.org.br/artigo/detalhes/1039

[41] Sousa, J.B., Vianna, A.L. and Oliveira, P.G. (2014) Marital Interactions in Partners of Ostomized Patients. Journal of Coloproctology, 49, 210-2015. http://www.scielo.br/pdf/jcol/v34n4/2237-9363-jcol-34-04-0210.pdf

[42] Oliveira, G.S., Bavaresco, M., Filipini, C.B., Rosado, S.R., Dázio, E.M.R. and Fava, S.M.C.L. (2014) Vivências do cuidador familiar de uma pessoa com estomia intestinal por câncer colorretal. Rev Rene, 15, 108-115. http://www.revistarene.ufc.br/revista/index.php/revista/article/view/1483

[43] Silva, J., Sonobe, H.M., Buetto, L.S., Santos, M.G., Lima, M.S. and Sasaki, V.D.M. (2014) Estratégias de ensino para o autocuidado de estomizados intestinais. Rev Rene, 15, 166-173. http://www.revistarene.ufc.br/revista/index.php/revista/article/viewFile/1379/pdf

[44] Cunha, R.R., Backes, V.M.S. and Heidemann, I.T.S.B. (2012) Desvelamento crítico da pessoa estomizada: Em ação o programa de educação permanente em saúde. Acta Paulista de Enfermagem, 25, 296-301. http://www.scielo.br/scielo.php?script=sci_arttext\&pid=S0103-21002012000200022 http://dx.doi.org/10.1590/s0103-21002012000200022

[45] Carvalho, E.C., Laus, A.M., Caliri, M.H.L., Rossi, L.G. and Rossi, L.G. (2010) Da produção à utilização de resultados de pesquisa na prática assistencial: Uma experiência em consolidação. Revista Brasileira de Enfermagem, 63, 853-888. http://www.scielo.br/pdf/reben/v63n5/27.pdf

[46] Raimondo, M.L., FegadoliI, D., Méier, M.J., Wall, M.L., Labronici, L.M. and Raimondo-Ferraz, M.I. (2012) Produção científica brasileira fundamentada na Teoria de Enfermagem de Orem: Revisão integrativa. Revista Brasileira de Enfermagem, 65, 529-534. http://www.scielo.br/scielo.php?script=sci_arttext\&pid=S0034-71672012000300020 http://dx.doi.org/10.1590/s0034-71672012000300020

[47] Oliveira, C.M., Carvalho, D.V., Peixoto, E.R.M., Camelo, L.V. and Salviano, M.E.M. (2012) Percepção da equipe de enfermagem sobre a implementação do processo de enfermagem em uma unidade de um hospital universitário. Revista Mineira de Enfermagem, 16, 258-263. http://www.reme.org.br/artigo/detalhes/527

[48] Nascimento, L.K.A.S., Medeiros, A.T.N., Saldanha, E.A., Tourinho. F.S.V., Santos, V.E.P. and Lira, A.L.B.C. (2012) Sistematização da assistência de Enfermagem a pacientes oncológicos: Uma revisão integrativa da literatura. Revista Gaúcha de Enfermagem, Porto Alegre, 33, 177-185. http://www.scielo.br/pdf/rgenf/v33n1/a23v33n1.pdf

\section{Submit or recommend next manuscript to SCIRP and we will provide best service for you:}

Accepting pre-submission inquiries through Email, Facebook, LinkedIn, Twitter, etc. A wide selection of journals (inclusive of 9 subjects, more than 200 journals)

Providing 24-hour high-quality service

User-friendly online submission system

Fair and swift peer-review system

Efficient typesetting and proofreading procedure

Display of the result of downloads and visits, as well as the number of cited articles

Maximum dissemination of your research work

Submit your manuscript at: http://papersubmission.scirp.org/ 